\title{
Environmental Soil Quality Research as Prediction for Sustainable Orchards Cultivation in Southern Serbia
}

\author{
Jelena Markovic ${ }^{1} \&$ Svetlana Stevović ${ }^{2}$ \\ ${ }^{1}$ Colledge of Applied Professional Studies, Filipa Filipovića 20, Vranje, Serbia \\ ${ }^{2}$ Faculty for Ecology and Environmental Protection, University Union Nikola Tesla, Belgrade, Serbia \\ Correspondence: Jelena Markovic, Colledge of Applied Professional Studies, Filipa Filipovića 20, Vranje, Serbia. \\ E-mail: gogaijeka@gmail.com
}

\author{
Received: March 3, 2015 Accepted: December 23, 2015 Online Published: January 15, 2016 \\ doi:10.5539/jas.v8n2p151 URL: http://dx.doi.org/10.5539/jas.v8n2p151
}

\begin{abstract}
Soil quality is one of the main environmental conditions for successful and sustainable orchards cultivation. The main role of the soil is reflected in its production activities or productivity. Soil fertility implies content available nutrients, such as individual elements, $\mathrm{pH}$ and humus. The research of soil quality leads to certain conclusions about which soil is suitable for growing crops. The investigation of soil quality for Pcinja District in southern Serbia is performed, with the goal to complete environmental conditions for cultivation of the most suitable crops. The methods that were used for the analysis of the soil in the laboratory are: chemical and Al-methods and calibration and potentiometric, spectrophotometric, photometric. For potentiometric method $\mathrm{pH}$ meter, spectrophotometer classic which is determined by phosphorus and Flame Photometar device that determines potassium are used. The results in this paper show high quality land for sustainable growing fruit crops.
\end{abstract}

Keywords: environment, soil, potassium, phosphorus, humus, methods

\section{Introduction}

The soils of the Vranje area have diverse productive properties. They are represented by two groups: agentic creations and genetic constructs. In agentic creations come skeleton, skeletoidal land formations and alluvial-diluvial deposits. Genetic constructs are represented by soil types: forest soil and its varieties, "smonica" and its varieties, "podzol" and traces mountain black soil. Genetic constructs occupy from $22 \%$ to $25 \%$ of the total area of Vranje region. Agenetic creations cover a large part of the area and occupy about $75 \%$ of the surface area. Gajnjača, smonica and podzol occupy an intermediate altitude of Vranje area and the tilting courts are eroded. Black soils are represented on the courts and in an area with sparse forests. In order to plant anything better and more suitable for the development of certain cultures, it is necessary to apply modern agro-technical measures, the implementation of various modern physical and chemical methods (Wang et al., 2013). Region of southern Serbia is suitable for the development and production of organic food. Organic production greatly affects the quality of soil, if the soil is rich in humus, the development of organic farming is better and bigger.

The plot is complex, live, variable and dynamic component of agroecosystems (Krnačova et al., 2013). It represents the portion of the Earth's crust where plants live and other microorganisms. The composition of the soil directly affects the anatomical structure of plants and their characteristics (Stevovi, 2010; Stevović et al., 2009). Development of appropriate soil analysis is especially important when it comes to growing medical plants (Stevović et al., 2011). From the standpoint of agriculture "perfect soil" should contain 45\% of minerals, 5\% of organic matter and $50 \%$ of the cavities, one of which should be half filled with air and half with water (Oljača, 2008). Good quality soil should be of good quality. Soil quality is reflected in the amount of chemical elements present at the most $\mathrm{N}$ (nitrogen), $\mathrm{P}$ (phosphorus) and $\mathrm{K}$ (potassium), of humus and the $\mathrm{pH}$ value, which is characterized by its fertility (Popovic, 1989; Steve \& Čalić-Dragosavac, 2010; Stevović et al., 2013). Nitrogen contained in the soil affects the normal flowering and fruiting, and it is also required in the synthesis of the enzyme, it enters into the composition of chlorophyll and its deficiency causes yellowing of the leaves (Oljača, 2008). Phosphorus contained in the soil is in the construction of nucleic acids, nucleoproteins, phytate, including some sugars. The plant absorbs it through the root system. Essentially soil is poor in phosphorus, and for this reason the soil constantly trash phosphorus fertilizers (Oljača, 2008). Potassium is essential for growth and cell division in plants and if it has more soil, the plants are more resistant to diseases and stress (Stevovi et al., 2010). 
Lack of potassium in the soil causes a disruption in water balance, or curling of leaves and root rot.

\section{Materials and Methods}

Pčinja District lies at the south of the Republic of Serbia in an area of 3,520 square kilometers $(3.98 \%$ of the territory of the Republic of Serbia). In the east its borders are Bulgaria, in the south of Macedonia and Albania, in the west of Kosovo and Metohija in the north of the Jablanica District. Pčinja District includes seven municipalities: Vranje, Bujanovac, Bosilegrad, Presevo, Vladičin Han and Surdulica. Landscape, environment, demographic trends and infrastructural facilities have contributed to the average density in this region it is 64.97 $\mathrm{km}^{2}$ which is significantly below the national average of 83.18. It has a population of 243,529 .

Pčinja District is represented by a moderate continental climate with some specifics. The average annual temperature is 12.4 degrees, the average air pressure is 966.2 and the relative humidity is $68 \%$. Pčinja District is rich in natural resources: the lake, which is since 2007 under the protection of UNESCO, Vranje Spa (known for the warmest water in Europe), Bujanovac Spa.

As the material in this study were determined using soil samples from various locations across the Pcinja District and villages: Rataje, Aleksandrovac, Zlatokop, Tibužde, Ranutovac.

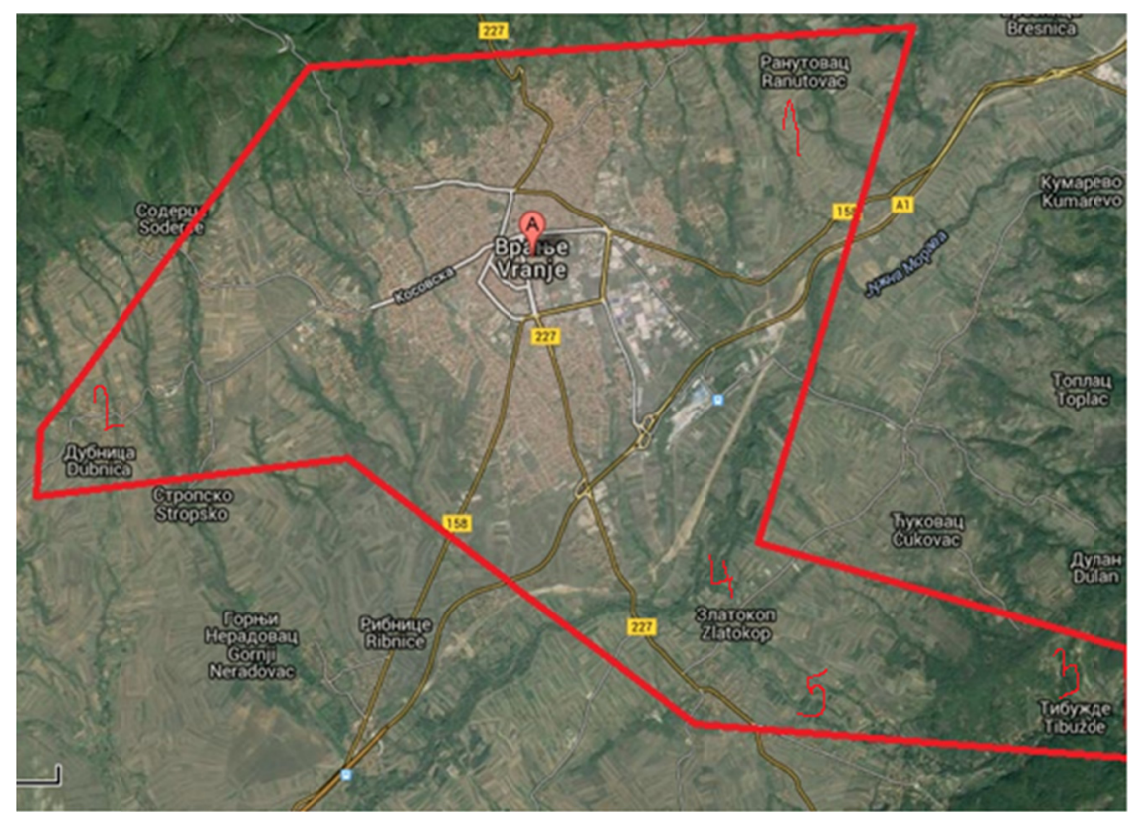

Figure 1. The satellite image of willages, locations were soil samples were taken

Among these, the two geographical integrit: VranjskaGraben and the Morava river. Graben basin consists of: Vranje, Bujanovac and Masurička valley. Vranje basin consists of two parts: the depression circumferential hills above the basins and valleys along the South Morava river with its tributaries in this area. Vranje-Bujanovac-basin consists of a unique concept in lowland area. The Southern Morava depression of the material consists of alluvial and Neogene sediments in lowland areas, and crystalline schists in the hills and mountainous part of Vranje region. In Vranje there are sandy and alluvial deposits and loose Neogene sediments. Neogene sediments consist mainly of shale, sandstone and conglomerate. From Vladičin Hana to Grdelica on the left side of the Morava, near the conglomerates occur and occur limestone, sandstone and marl.

The effect of soil quality is tested and presented in this paper. Testing was carried out in different locations and in a different period of a year. The parameters of soil quality, humus, $\mathrm{P}, \mathrm{K}, \mathrm{N}$, were determined by titration methods, calibration and f-metric methods. This test was carried out in order to find an area with the land that prone to the development of agricultural production.

Types of soil to be used for sampling are smonica and gajnjaca. Gajnjača and smonica are compacted clay soil. Gajnjača may have a rosy and brown color and is less fertile than smonica. Smonica is black in color, rich in 
humus and very fertile land. Since the composition and quality of soil depends on the quality of yield of a plant that is planted or sown. Soil samples that were used for the analysis were tested in an agricultural laboratory and extension services in Vranje. To get the best possible results and quality of the country sampling should be properly done. There are several methods of sampling, but the main are: sampling at smaller and larger lots. Soil samples for testing in this study were taken from smaller pitches and with a few of them. Samples were taken from the same cadastral parcels, from an area of soil that belongs to the same type and under the same culture. Individual samples were used. Samples were taken at a depth of $17 \mathrm{~cm}$, in the period after harvest (for crops) or prior to fertilization and during the growing season (for fruit crops). Methods that have been used for the sampling method are using the probe.
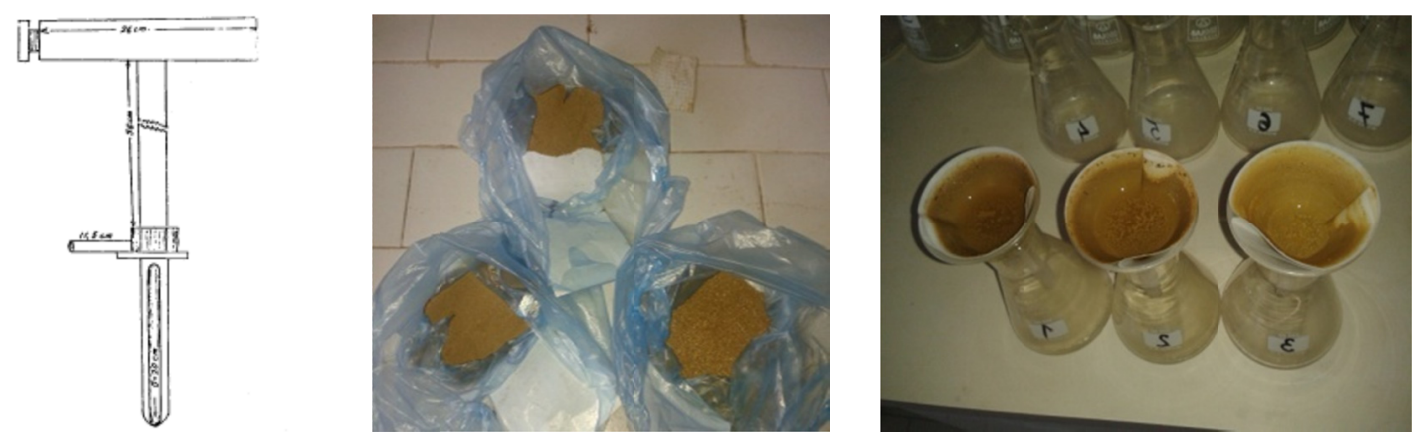

Figure 2. Probe for sampling soil, different soil samples, soil samples during filtration after $2 \mathrm{~h}$ of rotation of the carousel

Prior to field sampling, topographic and pedological maps are analyzed. There are chess and diagonal layout. In this paper, the chess schedule of sampling is used. Soil samples are mixed by hand in order to be chopped. If the weight of the earth is greater than the desired weight of the average of the sample, the elimination of the access of a part of the sample is used by means of eliminating the diagonal. The fragmented country schedules on paper is in the form of a square or rectangle, then a ruler is used to withdraw the diagonal, so that the country of the first two opposing triangles is away from paper and discarded, and the remaining land to the other two triangles again well mixed. Thus obtained samples were placed in paper bags on: sample number, the name of the farm, date of collection, name of the person taking the sample, label the plot, the depth at which the sample was taken and the type of soil. Soil samples are first dried and then tested. Dried samples were sieved in a sieve and only the fraction that passed through the sieve analyzes while the other ones are thrown away.

The methods that were used for the analysis of the country in the laboratory are: chemical and Al-methods and calibration and potentiometric, spectrophotometric, photometric. For potentiometric method $\mathrm{pH}$ meter, spectrophotometer classic which is determined by phosphorus and Flame Photometar device that determines potassium are used. These methods determined by the $\mathrm{pH}$ of the soil, the content of potassium, phosphorus, nitrogen and humus. Using a $\mathrm{pH}$ meter, measure the voltage, which is dependent on the activity of hydrogen ions in the suspension of land with water or with a normal solution of $\mathrm{KCl}$. To determine the content of potassium and phosphorus, calibration methods, weighed samples of soil, which is poured aera solution, placed on the apparatus so. carousel, where they are turned out to be $2 \mathrm{~h}$ resulted in a homogeneous state. Measurement of the spectrophotometer (Figure 3) is carried out at a wavelength of 830 millimicrons. They use red photocells. The staining intensity of the solution is measured in comparison to a blank, ie, the first member of a series of standards that are labeled "O", which is a pointer to the galvanometer leads to the zero graduation. The spectrophotometer is calibrated to the specific factor, which is darker in color and ionizing water. When you reset the camera approaches the reading of a series of standards and going from lower to higher concentrations, and then to read a series of samples of analyzed soils. The study of soil quality impacts on sustainable development and environmental protection, there by reducing the likelihood of potential pollution (Sobczyk, 2014).

In order to determine the content of potassium, phosphorus, nitrogen, humus and soil $\mathrm{pH}$ were used to dry soil samples. To determine the content of potassium and phosphorus was withdrawn at $5 \mathrm{~g}$ soil sample in which it is dispensed per $100 \mathrm{ml}$ aera solution and it was so dizzy, turned over to the so-called carousel for 2 hours. After the shaking of the filter paper spinning takes from 30 minutes to an hour depending on the type of soil. Filtered samples were calibrated spectrophotometer or photometer. 

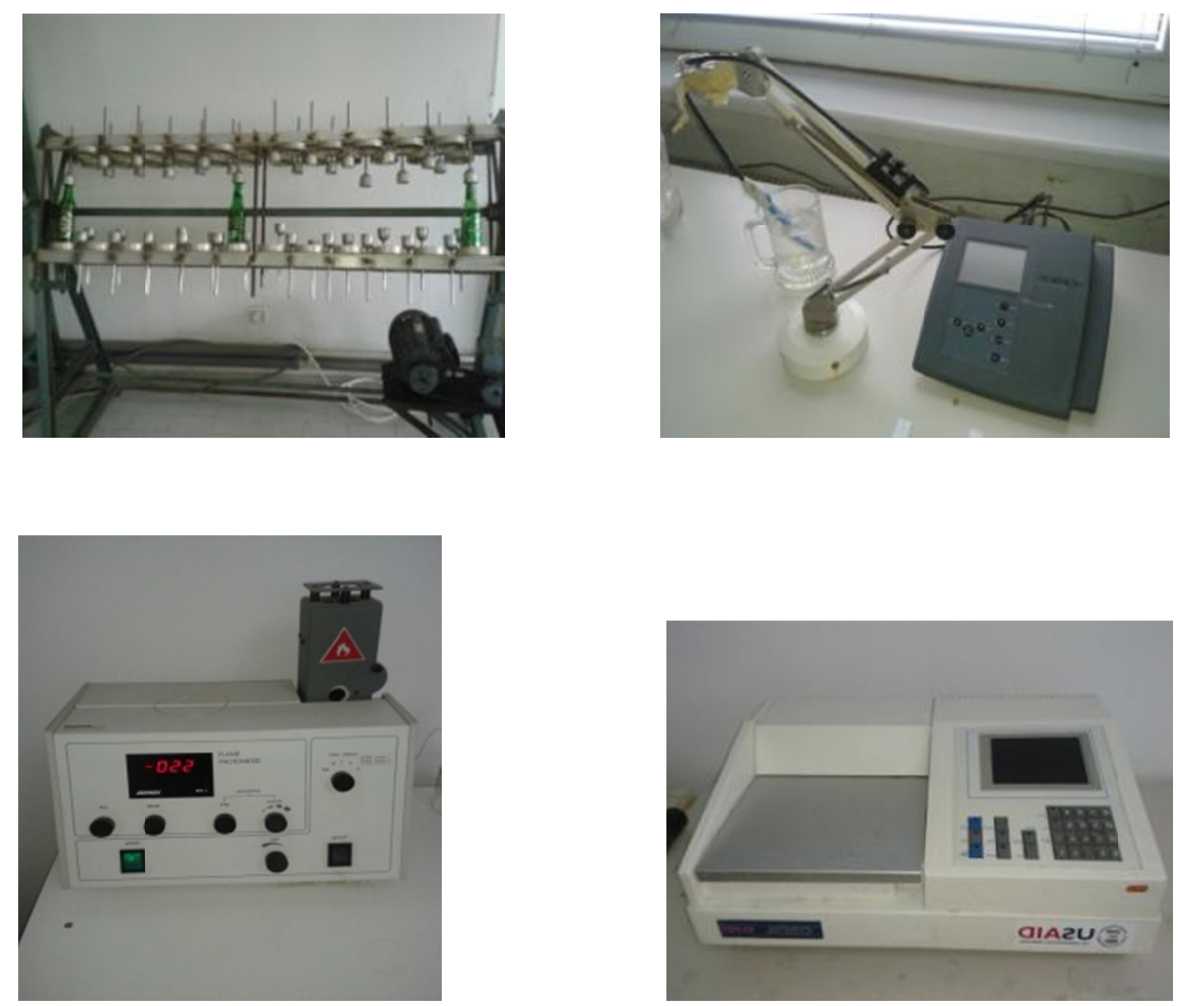

Figure 3. A device for turning, pH meter, Flame Photometar device and spectrophotometerwhich are ussed for testing

Samples to be tested are poured into a test tube and the sample is added to the molybdenum reagent and stanium chloride, after which the tube is placed in a dark place 15-30 minutes and only then placed in the spectrophotometer. The task of calibration is to establish what the cultivated crop means analysis revealed nutrient content, and from which other properties of the soil, the extent of this depends on the availability of nutrients for cultivated crops.

Calibration should show where the boundaries of bad and good level of supply of a lot of phosphorus, potassium and other nutrients are beyond which limit one can expect good or poor performance of all the phosphorus and potassium fertilizer (Manojlovic, Rajkovic, Glintić, \& Šestić, 1969). This is a method for determining the phosphorus content in the extracts by means of Al-molibden blue, in which a reducing fosfomolibden complex of ascorbic acid is used. Determination of humus, the method of titration with $\mathrm{KMnO}_{4}$ and oxalic acid. The procedure of this method is such that the measured sample in the country, distilled water was added, and sulfuric acid is introduced and kaliumpemaganat boil. This is a method of determining the humus by-Kotzman in. The percentage of humus is calculated by the following formula:

$$
\% \text { humus }=\frac{A \cdot 0.514 \cdot 1.72 \cdot 100}{C}
$$

Where,

A: Spent $\mathrm{ml}$ of $0.1 \mathrm{~N} \mathrm{KMnO}_{4}$ solution to oxidize the carbon in the sample studied; 0.514: Coefficient, which indicates that each $\mathrm{ml}$ of $0.1 \mathrm{~N} \mathrm{KMnO}_{4}$ oxidizes $0.514 \mathrm{mg} \mathrm{C}$ in $\mathrm{CO}_{2} ; 1.72$ : Coefficient for converting $\mathrm{mg} \mathrm{C}$ in humus; C: Taken probes country expressed in $\mathrm{mg}$; 100: number in scoring percentage.

First, gather the volume of $0.1 \mathrm{~N} \mathrm{KMnO}_{4}$ added before boiling for retitration, and multiplying by a factor translates the exact normality. Of this sum is subtracted the consumption of $0.1 \mathrm{~N}$ oxalic acid titration of the test probe area and the blanks. Difference " $A$ " represents the used amount of $0.1 \mathrm{~N} \mathrm{KMnO}_{4}$ solution to oxidize the carbon in tested soil samples. Factor of $0.1 \mathrm{~N} \mathrm{KMnO}_{4}$ solution was 1.0052 , and the factor of a $0.1 \mathrm{~N}$ oxalic acid solution is 0.9951 .

\section{Results and Discussion}

In order to determine the $\mathrm{pH}$ value is weighed to $10 \mathrm{~g}$ of soil samples which are then poured $25 \mathrm{ml} \mathrm{KCl}$, for 15 
minutes and then the $\mathrm{pH}$ values determined by using $\mathrm{pH}$ meter.

For the determination of the humus, $0.5 \mathrm{~g}$ of the analytical balance land is measured and $130 \mathrm{ml}$ of distilled water was poured $20 \mathrm{ml}$ of sulfuric acid and $50 \mathrm{ml}$ kaliumpermaganat, are cooked for 15-20 minutes, and then a titration is carried out with oxalic acid to discoloration, and then the sample discolored kaliumpermaganat titrated to the appearance of pink color. Specifying the humus and nitrogen is determined by the formula:

$$
\text { Nitrogen }=0.05 \times \text { humus }
$$

The test results of different soil samples were analyzed for the period from July 2013 to October 2014. The following results which are presented in tables.

Table 1. The content of various parameters in the examined samples of the country fruit crops the village (Figure 1), from which they take soil samples for testing (Ranutovac number 1, Zlatokop number 2, Tibuzde number 3, Aleksandrovac number 4, Dubnica number 5)

\begin{tabular}{|c|c|c|c|}
\hline & Consumed quantity of the oxalic acid in $\mathrm{ml}$ & Consumed quantityKMnO${ }_{4}$ in $\mathrm{ml}$ & The humus content in $\%$ \\
\hline Ranutovac & 38 & 2.4 & 3.27 \\
\hline Ranutovac & 39 & 1.8 & 2.98 \\
\hline Ranutovac & 40 & 4.4 & 3.29 \\
\hline Ranutovac & 40.1 & 4.5 & 3.30 \\
\hline Zlatokop & 41 & 1.5 & 2.57 \\
\hline Zlatokop & 43 & 1.5 & 2.21 \\
\hline Zlatokop & 41 & 3 & 2.85 \\
\hline Tibuzde & 42 & 3 & 2.67 \\
\hline Tibuzde & 40 & 5.3 & 3.14 \\
\hline Tibuzde & 42 & 5.9 & 3.23 \\
\hline Tibuzde & 38 & 4.9 & 3.75 \\
\hline Aleksandrovac & 38 & 4.5 & 3.67 \\
\hline Aleksandrovac & 38 & 2.4 & 3.27 \\
\hline Dubnica & 36.1 & 2 & 3.53 \\
\hline Dubnica & 39 & 3.7 & 3.43 \\
\hline
\end{tabular}

The numbers 1, 2, 3, 4 and 5 in Table 1 and Table 2, show the village (Figure 1), from which they take soil samples for testing (Ranutovac, Zlatokop, Tibuzde, Aleksandrovac, Dubnica). Table 1 shows the results of the analyzed soil samples from these locations. Column one and two (in Table 1) shows the number of $\mathrm{ml}$ of oxalic acid and kaliumpermaganat used for titration of the sample of the earth, in which, using the Equation 1 examines the content of humus. It can be seen from Table 1 that the humus content ranges in value from $2-4 \%$, depending on which culture was on that land. Larger values of humus show that the land is better suited for the cultivation of fruit crops and that the samples of the country, where there are larger amounts of humus are actually samples from the soil on which they fruit culture were planted. Fruit crops in the autumn, when they discontinue vegetation and they drop leaves, return to the soil organic matter, which is what enriches and creates a fertile land. Organic matter is decomposed into simpler compounds decomposition and mineralization (Strengthen, 2008). Higher values indicate that the humus soil better for growing plants, in this case fruit crops. The quantity and quality of humus in the soil is constantly renewed, or the amount of new topsoil to replace old and thus maintains a certain level of humus in the soil, which is intended for planting some crops. This balance is of great importance for the creation and maintenance of soil fertility (Oljača, 2008). Successive changes significantly affecting the quality of agricultural land (Špulerova, 2008).

What can also be observed from Table 1, in conjunction with humus, is that the value of humus increases in the fall. With the increased work of the microorganism. Solid land for the cultivation of fruit crops is considered that when the value of humus is around 3 , and the research found this. 
Table 2. The content of the parameter K, F, N, and the pH of the assay samples the village (Figure 1), from which they take soil samples for testing (Ranutovac number 1, Zlatokop number 2, Tibuzde number 3, Aleksandrovac number 4, Dubnica number 5)

\begin{tabular}{|c|c|c|c|c|}
\hline & The humus content $\mathrm{K}$ in $\%$ & The humus content $\mathrm{P}$ in $\%$ & The humus content $\mathrm{N}$ in $\%$ & $\mathrm{pH}$ \\
\hline Ranutovac & $K(26)=9.64$ & 9.51 & 0.16 & 6.22 \\
\hline Ranutovac & $K(27)=10$ & 12.52 & 0.15 & 5.59 \\
\hline Ranutovac & $\mathrm{K}(37)=13.85$ & 14.78 & 0.16 & 5.57 \\
\hline Ranutovac & $K(39)=14.62$ & 20.40 & 0.16 & 6.38 \\
\hline Zlatokop & $K(17)=6.43$ & 27.20 & 0.13 & 6.93 \\
\hline Zlatokop & $K(14)=5.38$ & 13.62 & 0.11 & 6.52 \\
\hline Zlatokop & $K(36)=13.46$ & 23.66 & 0.14 & 6.61 \\
\hline Tibuzde & $\mathrm{K}(35)=13.08$ & 21.60 & 0.13 & 6.86 \\
\hline Tibuzde & $\mathrm{K}(32)=11.92$ & 10.13 & 0.17 & 3.81 \\
\hline Tibuzde & $K(27)=10$ & 13.48 & 0.16 & 3.74 \\
\hline Aleksandrovac & $\mathrm{K}(34)=12.69$ & 17.12 & 0.19 & 5.03 \\
\hline Aleksandrovac & $\mathrm{K}(211)>40$ & 21.25 & 0.20 & 5.44 \\
\hline Aleksandrovac & $\mathrm{K}(121)>40$ & 16.90 & 0.18 & 5.45 \\
\hline Dubnica & $K(26)=9.64$ & 8.93 & 0.18 & 4.04 \\
\hline Dubnica & $\mathrm{K}(258)>40$ & $>40$ & 0.32 & 7.5 \\
\hline Dubnica & $K(36)=13.46$ & 14.16 & 0.18 & 4.62 \\
\hline Dubnica & $\mathrm{K}(28)=10.38$ & 9.78 & 0.16 & 5.17 \\
\hline Ranutovac & $\mathrm{K}(1200)>40$ & $>40$ & 0.46 & 6.75 \\
\hline Ranutovac & $\mathrm{K}(32)=11.92$ & 10.61 & 0.17 & 4.03 \\
\hline
\end{tabular}

From Table 2, we see that the $\mathrm{pH}$ value of the soil generally ranges from 3 to 6 . This means that for the growth and further growth of the plants most suitable are acid soils, which are in the range of 6 to 8 . From Table 2, one can see the value of $\mathrm{pH} 3.81$ and 3.74 of land like this are not recommended for planting seedlings, as reduced $\mathrm{pH}$ value can cause an increase in the concentration of aluminum and manganese to toxic values (Kovačević, 2003). In the samples in which a $\mathrm{pH}$ of about 7 the solubility of phosphorus is best.

The value of potassium $(\mathrm{K})$ in Table 2 was obtained by the reading value of the Flame Photometar device at a given value, for example. The device is for a sample of countries alleged value so that the number 34 corresponds to the value of $\$ 12.69$, and so for all values.

The values of phosphorus in Al-extract samples, listed in Table 2 were obtained from the values of individual members of a series of standards. On the basis of these calibration curve can be constructed in apcis is applied in the soil content of phosphorus in $\mathrm{mg}$ per $100 \mathrm{~g}$ of the $\mathrm{P}_{2} \mathrm{O}_{5}$ to the earth and in relation to 10:1. The last member of the standard solution, corresponding to the content of $40 \mathrm{mg}$ per $100 \mathrm{~g} \mathrm{P}_{2} \mathrm{O}_{5}$ country and that means that apcis be $40 \mathrm{~cm}$ long. The ordinate is applied to values read from the device. At the intersection of these values are the points that give the associated calibration curve, which actually represent the results. Results of testing samples show the presence of solid potassium and phosphorus as well as nitrogen and therefore can be said to have samples of soil suitable for growing plants. You can say that, fruit crops are planted on such land will give good yields, ie there will be no deterioration and decay, but such land shall periodically fertilized to obtain maximum yields. The only climatic factors can affect a significant impact.

In Table 2 one can see the values of potassium and phosphorus that are greater than 40 . This means that when the values of potassium and phosphorus is greater than 40 (which is an upper limit, maximum), the land does not need to muck with the kinds of fertilizers are composed of potassium and phosphorus. It is believed that in the land which is investigated the content of potassium and phosphorus is over 40, self-sufficient without the addition of additional fertilizer. 
Based on the results of testing samples it can be concluded that the parameters that determine soil quality are satisfactory for the cultivation of fruit crops provided. This favorable results are influenced by favorable environmental factors, as well as good geographical position. Ecological factors (especially climate) are very important and their impact on soil quality is of great importance (Misic, 1964) alue of phosphorus in the studied samples in $100 \mathrm{~g}$ of soil. However, stakeholders desired future development and their perceptions of agricultural landscape values varied according to different pressures in the individual studied areas (Barankova et al., 2011).

\section{Conclusion}

This paper is research of the different soil samples from different locations and samples taken at different times of the year. Test results that were obtained showed that the samples examined countries solid quality, but considering that it comes loam type of soil and forest soil, then the obtained results are also good. Test results showed that the samples of soil are mainly with $\mathrm{pH}$ around 7 , that are acidic; that some samples of the country does not need aditional fertilizing as they are rich in phosphorus and potassium (phosphorus and potassium have values greater than 40). Results showed that soil is rich in humus because of all the samples of humus value is around 3-3.5. Based on the obtained results, it can be concluded that the tested soil samples are suitable for the cultivation of fruit crops and the region of Southern Serbia can develop in that direction. That the results of research conducted soil confirms the correctness of orientation towards the cultivation, which opens the posibility of organic cultivation and at the same time contributing to sustainable rural development in the region southern Serbia. The results are presented in the form of potential methods of developing fruit production in southern Serbia (Ciyler, 2013).

\section{Acknowledgements}

This work was supported by the Ministry of Science and Environment Protection of Serbia under the grant No. EE18031 and TR35030.

\section{References}

Barankova, Z., Dobrovodska, M., Štefunkova, D., Babicova, D., Moyzeova, M., \& Petrović, F. (2011), Participation of local people on indentifyng the landscape values and future development in historical agricultural landscapes , Ekol. Bratislava, 30(2), 216-228. http://dx.doi.org/10.4149/ekol_2011_02_216

Cizler, J. (2013). Opportunities for the Sustainable Development of Rural Areas un Serbia Problemy ekorozwoju. Problems of Sustainable Development, 8(2), 85-91.

Kovacevic, D. (2003). General Field (p. 771). Faculty of Agriculture, Belgrade.

Krnačova, Z., Hreško, J., Kanka, R., \& Boltižar, M. (2013). The evaluation of ecological factors affecting environmental functions of the soils in area of traditional agrarian structures, Ekol. Bratislava, 32(2), 24.

Manojlovic, S., Rajkovic, Ž., Glintić, M., \& Šestić, S. (1969). Handbook for Systematic control of soil fertility and fertilizer. Belgrade.

Misic, V. (1964). Ecological factors and their significance in the plant world. Belgrade.

Oljača, S. (2008). Agroecology edition. Faculty of Agriculture, Belgrade.

Popovic, Z. (1989). Agrohemija. Scientific Book, Belgrade.

Sobczyk, W. (2014). Sustainable development of rural areas Problemy ekorozwoju. Problems of Sustainable Development, 9(1), 119-126.

Stevanovic, B., \& Jankovic, M. (2001). Ecology of plants with the fundamentals of the physiological ecology of plants (p. 514). NNK International, Belgrade.

Stevovi, S. (2010). Environmental impact on morphological and anatomical structure of Tansy. African Journal of Biotechnology, 9(16), 2413-21.

Stevovi, S., \& Calice-Dragosavac, D. (2010). Environmental study of heavy metalsinfluence on soil and Tansy (Tanacetum vulgare L.). African Journal of Biotechnology, 9(16), 2392-400.

Stevovic, S., Dervnja, N., \& Čalić-Dragosavac, B. (2013). Environmental impact quantification and correlation between site location and contents and structure of Tansy. African Journal of Biotechnology, 10(26), 5075-83.

Stevovic, S., Mikovilović, V. S., \& Čalić-Dragosavac, B. (2010). Environmental impact of site location on marco-and microelements in Tansy. African Journal of Biotechnology, 9(16), 2408-12.

Stevovic, S., Mikovilović, V. S., \& Dragosavac, D. C. (2009). Environmental adaptibility of tansy (Tanacetum 
vulgare L.). African Journal of Biotechnology, 8(22).

Stevović, S., et al. (2011). Correlation Between Environment and Essential Oil Production in Medical Plants. Advances in Environmental Biology, 5(2), 465-68.

Špulerova, J. (2008). Succession changes in extensively used agricultural land Ekol. Bratislava, 27(1), 54-64.

Wang, Z., Fan, M., \& John, I. (2013). Beyond The Dilemma Facing China's Agricuture - Toward a Chinese Constructive Postmodern Agriculture, Problemy ekorozwoju. Problems of Sustainable Development, 8(1), 43-56.

\section{Copyrights}

Copyright for this article is retained by the author(s), with first publication rights granted to the journal.

This is an open-access article distributed under the terms and conditions of the Creative Commons Attribution license (http://creativecommons.org/licenses/by/3.0/). 